Інноватика у вихованні. Випуск 11. Том 1. 2020.

УДК 378.456:234

DOI: $10.35619 /$ iiu.v1i11.269

Довбенко Світлана,

кандидат педагогічних наук, доцент кафедри педагогіки початкової освіти Прикарпатського національного університету імені Василя Стефаника, м. Івано-Франківськ, Україна

ORCID: 0000-0003-2316-0579

e-mail:svitlana.dovbenko@pnu.edu.ua

\title{
ФОРМУВАННЯ ПРОФЕСІЙНОЇ КОМПЕТЕНТНОСТІ МАЙБУТНІХ ФАХІВЦІВ ЯК ПЕДАГОГІЧНА ПРОБЛЕМА
}

\begin{abstract}
Анотація. Нові виклики вимагають адекватної модернізації освітньої системи як провідного чинника соціально-культурного відтворення, успішної життєдіяльності людини, іiї подальшого вдосконалення. Нині українська держава потребує не стільки великої кількості фахівців, скільки фахівців, здатних до «прориву» у найважливіших галузях промисловості та сферах суспільного життя, 3 гуманістичним способом мислення та універсальними знаннями. Це породжує цільове підгрунтя нашої наукової розвідки, що полягає в актуалізації необхідності фундаменталізації компетентнісної складової професійної підготовки майбутніх фахівців у ЗВО.
\end{abstract}

Концептуальною основою компетентнісного підходу, як нового методологічного інструментарію у світовій практиці та освіті, $є$ ідея компетентності та ключових компетенцій, що сформувалась як один 3 найефективніших способів подолання протиріч в освіті та суспільстві, яке потребує компетентних фахівців, здатних до самоудосконалення та постійного оновлення своїх знань.

Свроінтеграція України, посилення «статусності» компетентнісного підходу в офіційних вітчизняних та міжнародних освітніх документах переорієнтовують традиційну освітню парадигму 3 трансляції готового знання, формування вмінь $\mathrm{i}$ навичок на створення у закладі освіти умов для оволодіння студентами комплексом компетенцій та формування їх професійної компетентності, тобто готовності випускника до самостійної, відповідальної, продуктивної практичної діяльності та гнучкості у вирішенні особистих і професійних завдань.

Нині в науковій літературі поняття «компетентність» розглядається як характеристика особистості, результат освіти професіонала (посадової особи). Тобто поняття «компетентність» слід розглядати як складну, багатогранну інтегративну здатність особистості вирішувати професійні проблеми на основі досвіду і компетенцій. Зміни, що відбуваються в галузі визначення цілей освіти, співвідносні 3 глобальним завданням забезпечення входження людини в соціальний світ, іiі продуктивну адаптацію в цьому світі, а також обумовлюють необхідність постановки питання забезпечення освітою більш повного, особистісно і соціально інтегрованого результату.

Ключові слова: компетентність, компетенції, компетентнісний підхід, майбутні фахівці, вища школа.

Постановка проблеми. Нині українське суспільство перебуває під впливом потужних глобалізаційних процесів, швидких змін умов життя, посилення 
конкурентних засад та утвердження дослідницько-інноваційного типу розвитку, переосмислення ціннісних орієнтирів і стратегій людського буття. Тому головною метою модернізації освіти є посилення професійної підготовки фахівців, здатних компетентно вирішувати виробничі та наукові завдання.

Стратегічні завдання освіти, вимоги до рівня професійної підготовки майбутніх спеціалістів вимагають визнання особистістю провідної ролі розвитку інтелектуального ресурсу упродовж усього життя, необхідності саморозвитку та самоудосконалення в особистісній і професійній сферах. Ці та інші завдання визначені в Законах України «Про загальну середню освіту», «Про вищу освіту», Державній національній програмі «Освіта» (Україна XXI ст.), а також відображені в основних принципах розвитку вищої освіти України у контексті Болонського процесу. Однією з головних причин розгляду результату освіти крізь призму понять «компетенції», «компетентність» і реалізації компетентнісного підходу є його зумовленість загальноєвропейською та світовою тенденцією інтеграції, глобалізації світової економіки $з$ процесом побудови європейської системи вищої освіти.

Аналіз останніх досліджень 3 проблеми. Проблемі впровадження компетентнісного підходу в сучасну вищу освіту присвятили свої наукові доробки науковці А. Алексюк, І. Бібік, В. Бондар, В. Свдокимов, І. Ковчина, В. Козаков, Т. Крилова, В. Кузь, І. Мельничук, Л. Нічуговська, В. Олійник, П. Підкасистий, Л. Романишина, О. Романовський, М. Шкіль, О. Ярошенко та ін., які у різні періоди розвитку вітчизняної освітньої галузі намагалися розмежувати зміст понять «компетентність» та «компетенція». Однак і надалі в науці спостерігається плюралізм думок, що підтверджує актуальність наукової розвідки.

Мета статті - проаналізувати специфіку формування професійної компетентності майбутніх фахівців в умовах євроінтеграційного розвитку сучасної вищої школи.

Виклад основного матеріалу дослідження. Імплементація компетентнісного підходу з метою удосконалення системи освіти в європейських країнах почалася на початку 90-х рр. XX ст. Перш за все, це пов'язано із становленням демократії, громадянського суспільства та розвинених ринкових відносин (Бургун, 2015). Здійснюючи ретроспективний аналіз розвитку ідей компетентнісного підходу в освіті, Х. Плецан зазначає, що в доповіді Міжнародної комісії ЮНЕСКО «Освіта. Прихований скарб» окреслено базові принципи їі розвитку - навчись пізнавати, робити, жити разом, - які пізніше отримали назву «глобальні компетентності» (Плецан, 2018). На симпозіумі в м. Берн у програмі Ради Свропи було окреслено одну 3 проблем реформування освіти, що полягає у визначенні ключових компетенцій, якими повинні оволодіти студенти в процесі професійної підготовки (Козак, 2018). Наступним кроком упровадження компетентнісного підходу в освіті було підписання Лісабонської конвенції «Про визнання кваліфікацій вищої освіти в європейському просторі», в якій сформульовано концепцію міжнародного визнання результатів освіти та окреслено необхідність вироблення конвертованих загальнозрозумілих критеріїв такого визнання.

Знаковою для Свропи стала прийнята в Болоньї Декларація про європейський простір вищої освіти, підписана міністрами освіти 29 держав світу в т.ч. й Україною, пріоритетним завданням якої визнано якість освіти. Європейські університети розглядають компетентнісний підхід як інструмент, що забезпечує соціальний діалог вищої школи 3 роботодавцями, їх співпрацю та підтримку взаємної довіри в нових умовах. 
У цьому ж контексті було розроблено спільну освітню платформу «Ключові компетентності для навчання упродовж життя. Свропейська довідкова система» (Key Competences for Lifelong Learning. A European Reference Framework, 2005), затверджену Свропарламентом та Радою Європи в 2005 році. Після Болонського процесу була прийнята Рамка кваліфікацій європейського простору вищої освіти (EQF) (Key Data on Education in Europe, 2009) - інструмент зіставлення академічних ступенів i кваліфікацій у країнах ЄС. Подальшого розвитку i практичного застосування компетентнісний підхід набув шляхом опублікування фундаментального звіту «Кеу Data on Education in Europe, 2009», у якому наголошено на необхідності навчання упродовж життя задля досягнення ключових компетентностей, які не лише дадуть змогу молоді ввійти в доросле життя, а й сформують професійні навички для подальшого самоудосконалення (Key Data on Education in Europe, 2009). Значний внесок у розроблення компетентностей, спільних для всіх країн Європейського Союзу, вніс фінський проєкт «The Higher Education Curricula in the EU, 2010», у межах якого компетентнісний підхід розглядається як інструмент зміщення акцентів в освітній парадигмі від процесуальної до результативної її складової, від знеособленої до особистісної орієнтації (The Higher Education Curricula in the EU, 2010).

Як зазначає В. Овсієнко, остання версія Міжнародної стандартної класифікації освіти 2011 р. (МСКО-2011), як і МСКО-2013, у своїй концептуальній основі підтверджують необхідність використання компетентнісного підходу з метою орієнтаційної організації освітніх програм та відповідних кваліфікацій у галузі освіти та підготовки, щодо галузевої структуризації освітніх програм і досягнень («learning outcomes») (Овсієнко, 2017).

3 метою осучаснення освітньо-наукового законодавства в Україні та на основі окреслених методологічних, теоретичних, емпіричних і методичних європейських здобутків наприкінці 2011 року розроблено Національну рамку кваліфікацій (НРК), у якій, як і в Законі України «Про вищу освіту» (Закон України «Про вищу освіту», 2014), компетентнісний підхід в освіті визначено основним для забезпечення вимірюваної та порівнюваної освітньої якості, а також окреслюють конкретні компетенції для різних освітніх рівнів.

Отже, компетентнісний підхід орієнтований на досягнення кінцевого результату освіти, тобто на перехід від теоретичних знань до професійної компетентності (Біскул, 2018). Тому, для визначення сутності поняття «професійна компетентність», а в контексті дослідження - «професійна компетентність майбутніх фахівців», необхідним $є$ розмежування дефініцій «компетенції i компетентність».

Етимологія поняття «компетенція» (від лат. compete, нім. kompetenz, фp. competency) згідно тлумачних словників української мови та іншомовних слів має різні семантичні тлумачення: 1) відповідати, підходити, добиватись; 2) хороша обізнаність з будь-яких питань або у певній сфері знання; 3) формальне коло повноважень конкретного органу або посадової особи; 4) знання і досвід у конкретній сфері.

Досліджуючи компетенції у професійній освіті, Х. Плецан розглядає їх як міру освітнього успіху особистості, що виявляється під час виконання дій у професійних i соціально важливих ситуаціях (Плецан, 2018). На його думку, компетенції поділяються на професійні (професійно зорієнтовані), загальні (ключові, базові, універсальні, транспредметні, метапрофесійні, надпрофесійні тощо) та академічні. Метапрофесійні компетенції тлумачаться як готовність діяти цілевідповідно, методично організовано, уміння самостійно вирішувати завдання і проблеми, 
критично оцінювати результати власної діяльності. Загальні компетенції розглядаються як здатність, що грунтуються на знаннях, досвіді, цінностях, схильностях, які набуваються у всіх типах освітньої практики: формальної, неформальної, інформальної. Академічні компетенції інтерпретуються як оволодіння методологією і термінологією, властивій будь-якій галузі знань, усвідомлення діючих у ній системних взаємозв'язків та їх аксіоматичних меж.

У якості концептуального визначення поняття «компетенція» розглянемо формулювання, прописане у проєкті Європейського союзу TUNING, де зазначено, що поняття компетенцій і навичок охоплює знання та розуміння (здатність знати і розуміти), знання як діяти (практичне й оперативне застосування знань у конкретних ситуаціях), знання як бути (цінності як невід'ємна частина способу сприйняття і життя в соціальному контексті). Компетенції - це поєднання характеристик, що стосуються знань та їх застосування, позицій, навичок i відповідальності, які описують рівень, на якому певна особа здатна ці компетенції реалізувати.

У межах окресленого проєкту компетенції поділені на загальні (інструментальні, міжособистісні, системні) та спеціальні (професійні). Відтак, для поглибленого розкриття сутності компетенції необхідно виокремити та конкретизувати іiі основні характеристики (рис. 1.):

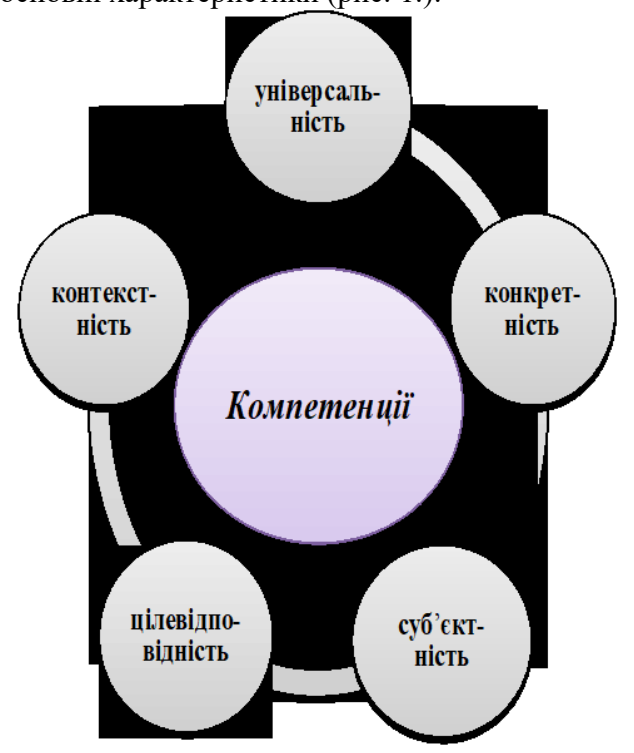

Рис. 1. Основні характеристики компетенції

1) універсальність - основне призначення i сутність застосування цієї компетенції полягає у формуванні уявлень людей про передумови їх успішної діяльності. Тому вони повинні мати універсальний характер, бути відтворюваними, оскільки можуть стосуватися різних людей;

2) суб'єктність - компетенції завжди адресовані певному суб'єкту;

3) конкретність - компетенції завжди конкретні, оскільки вони використовуються для прогнозування успішної діяльності, її оцінки, визначення напряму і змісту подальшого навчання та формування професійних стандартів, тому вони повинні відображатись у термінах завдань і дій; 
4) цілевідповідність - компетенції, як уявлення про успішну діяльність, повинні відповідати цілям діяльності і заздалегідь допомагати визначати суттєві параметри результатів діяльності;

5) контекстність компетенцій полягає у належності до конкретних процесів і професійних функцій; проте важливо дотримуватися балансу між загальними компетенціями, що мають широкий діапазон застосування, та спеціальними, орієнтованими на вирішення конкретних завдань.

Результатом набуття компетенції (наперед заданої соціальної норми (вимоги) до освітньої підготовки фахівця, необхідної для його якісної продуктивної діяльності в певній сфері та $\epsilon$ соціально закріпленим результатом) $\epsilon$ компетентність, яка «передбачає особистісну характеристику, ставлення до предмета діяльності». Поняття «компетентність» у педагогіці широко використовується з 80-х років XX ст. у значенні «освітній результат діяльності» особи, що навчається, а також як напрям модернізації професійної освіти.

Розширене розуміння сутності компетентності фахівця знаходимо в дослідженні А. Вербицького, який визначає компетентність як динамічну якість, що розвивається від отриманого в системі професійної освіти набору професійних якостей початкового рівня (освіченості) до вищої форми компетентності (майстерності). На думку науковця, формування компетентності передбачає безперервний процес, який не обмежений лише професійною підготовкою, оскільки компетентністю $є$ комплекс компетенцій, характеристики актуальної або реальної якості, сформовані головним чином у міру накопичення досвіду в певній професійної діяльності.

Як характеристика професіонала, компетентність зазвичай використовується у словосполученні «професійна компетентність», яка, як новий орієнтуючий вектор сучасної парадигми освіти щодо підготовки майбутніх фахівців, має забезпечувати переосмислення досвіду їх підготовки, враховувати такі принципово нові підходи до їі обгрунтування:

- розуміння необхідності обгрунтування методології формування професійної компетентності майбутнього фахівця конкретної галузі у процесі його професійної підготовки в 3ВО;

- пошук адекватних теоретичних засад щодо дослідження педагогікою, психологією, філософією освіти, соціологією, інформатикою та юриспруденцією педагогічних явищ, які стосуються формування професійних компетенцій майбутнього фахівця у процесі його підготовки в ЗВО;

- розуміння необхідності формування професійної компетентності фахівця як під час навчальної, так і позааудиторної роботи;

- вивчення, систематизація і творче використання позитивного національного та світового передового досвіду формування компетенцій майбутніх фахівців у 3BO.

Висновки і перспективи подальших розвідок. Отже, сучасні зміни характеру освіти (спрямованість, цілі, зміст) орієнтують іiі на «вільний розвиток людини», на творчу ініціативу, самостійність, конкурентоздатність, мобільність майбутнього фахівця. Ці накопичені зміни означають і зміни освітньої парадигми. Так, існуюча тривалий час «ЗУН - парадигма результату освіти» містить теоретичне обгрунтування, визначення, номенклатуру, ієрархію вмінь і навичок, методик їх формування, контролю й оцінки. Ця парадигма визнається частиною педагогів і донині. В якості загального визначення такого інтегрального соціальноособистісно-поведінкового феномену, як результат освіти в сукупності мотиваційно-ціннісних i когнітивних складових, виступає поняття 
«компетенція/компетентність», зміст якого змінює існуючу i формує нову парадигму сучасної вищої освіти.

Перспективи подальших розвідок вбачаємо у дослідженні потенційних дидактичних можливостей компетентнісного підходу як методологічного орієнтира сучасної вищої освіти.

\section{СПИСОК ВИКОРИСТАНИХ ДЖЕРЕЛ}

Бургун, I. (2015). Актуальність упровадження компетентнісного підходу в освітню практику. Актуальні проблеми державного управління, педагогіки та психологіï. № 1 (2). Херсон. С. 159-165.

Козак, Х. (2018). Сучасні проблеми фахової підготовки, професійної компетентності і професійної реалізації майбутніх медичних. В регіонар. наук.практ. конф. : Компетентнісний підхід у гуманітарній підготовиі майбутніх фахівиів медичної галузі. Тернопіль: «Вектор». С. 41-43.

Овсієнко, Л. (2017). Компетентнісний підхід до навчання: теоретичний аналіз. Педагогічний процес: теорія і практика. № 2 (57). Серія: педагогіка. С. 82-87.

Біскул, В. (2018). Принципи та технології компетентнісного підходу до формування професійної кар'єрної студентської молоді. Sociology. № 5 (133). С. 6167.

Про вищу освіту: Закон України (2014). Відомості Верховної Ради України $(B В P)$. № 37-38. C. 16-27. URL: http://zakon2.rada.gov.ua/laws/show/1556-18 [Дата звернення: 10.10 .2019$]$.

Плецан, Х. (2018). Стан та тенденції розвитку формування конкурентоздатного фахівця в умовах пошуку нової парадигми в сфері туризму. Економіка і держава. №6. C. 115-123.

Key Competences for Lifelong Learning. A European Reference Framework (2005). European Commission. Brussels : European Commission, 16 p.

Key Data on Education in Europe (2009). URL: http://eacea.ec.europa.eu/education/eurydice/documents/key_data_series/105en.p df (Accessed 10 October 2019)

The European Qualifications Framework for Lifelong Learning (EQF) (2008). European Commission. Luxembourg: Office for Official Publications of the European Communities, $15 \mathrm{p}$.

The Higher Education Curricula in the EU (2010). URL: http://ec.europa.eu/education/school-ucation/doc/teacherreport.pdf. [Accessed 10 October 2019].

\section{REFERENCES}

Burgun, I. (2015) Aktualnist uprovadzhennia kompetentnisnoho pidkhodu v osvitniu praktyku. [The Urgency of Implementation of a Competency-Based Approach in Educational Practice]. Aktualni problemy derzhavnoho upravlinnia, pedahohiky ta psykholohii. Kherson. No. 1(2), p. 159-165. (in Ukrainian)

Kozak, Kh. (2018). Suchasni problemy fakhovoi pidhotovky, profesiinoi kompetentnosti i profesiinoi realizatsii maibutnikh medychnykh [Modern Issues of Professional Training, Professional Competence and Professional Realization of Future Medical Practitioners]. V rehionar. nauk.-prakt. konf.: Kompetentnisnyi pidkhid u humanitarnii pidhotovtsi maibutnikh fakhivtsiv medychnoi haluzi. Ternopil: "Vektor", p. 41-43. (in Ukrainian) 
Ovsiienko, L. (2017). Kompetentnisnyi pidkhid do navchannia: teoretychnyi analiz [Competence Approach to Learning: Theoretical Analysis]. Pedahohichnyi protses: teoriia i praktyka. Seriia: pedahohika. No. 2(57), p. 82-87. (in Ukrainian)

Biskul, V. (2018). Pryntsypy ta tekhnolohii kompetentnisnoho pidkhodu do formuvannia profesiinoi kariernoi studentskoi molodi [Principles and Technologies of Competence Approach to the Formation of Professional Career of Student Youth]. Sociology. No. 5(133), p. 61-67. (in Ukrainian)

Pro vyshchu osvitu: Zakon Ukrainy [On Higher Education: Law of Ukraine] (2014). Vidomosti Verkhovnoi Rady Ukrainy (VVR). No. 37-38, p. 16-27. URL: http://zakon2.rada.gov.ua/laws/show/1556-18 [Data dostupu 10 October 2019] (in Ukrainian)

Pletsan, Kh. (2018). Stan ta tendentsii rozvytku formuvannia konkurentozdatnoho fakhivtsia v umovakh poshuku novoi paradyhmy v sferi turyzmu [The State and Trends in the Formation of a Competitive Specialist in Terms of Finding a New Paradigm in the Field of Tourism]. Ekonomika i derzhava. No. 6, p. 115-123. (in Ukrainian)

Key Competences for Lifelong Learning. A European Reference Framework (2005). European Commission. Brussels : European Commission, 16 p.

Key Data on Education in Europe (2009). URL: http://eacea.ec.europa.eu/education/eurydice/documents/key_data_series/105en.pdf (Accessed 10 October 2019)

The European Qualifications Framework for Lifelong Learning (EQF) (2008). European Commission. Luxembourg: Office for Official Publications of the European Communities, $15 \mathrm{p}$.

The Higher Education Curricula in the EU (2010). URL: URL: http://ec.europa.eu/education/school-ucation/doc/teacherreport.pdf. (Accessed 10 October 2019)

\title{
FORMATION OF PROFESSIONAL COMPETENCE OF FUTURE SPECIALISTS AS A PEDAGOGICAL PROBLEM
}

\author{
Svitlana Dovbenko \\ Candidate of Pedagogical Sciences, Associate Professor \\ at the Department of Pedagogy of Primary Education, \\ SHEI "Vasyl Stefanyk Prykarpattia National University", \\ Ivano-Frankivsk, Ukraine \\ ORCID: 0000-0003-2316-0579 \\ e-mail: svitlana.dovbenko@pnu.edu.ua
}

\begin{abstract}
New challenges require adequate modernization of the educational system as a leading factor in socio-cultural reproduction, successful human life, its further improvement. Nowadays, the Ukrainian state needs not so much a large number of specialists but specialists capable of a "breakthrough" in the most important industries and spheres of public life, with a humanistic way of thinking and universality of knowledge. This creates a targeted basis for our scientific research, which is to actualize the need for fundamentalization of the competency component of professional training of future specialists in higher educational institutions (HEIs). The conceptual basis of the competency approach as a new methodological tool in world practice and education is the idea of competence and key competencies, which established as one of the most effective ways to resolve contradictions in the development of education and society, which makes a person update his/her knowledge throughout life.
\end{abstract}


Ukraine's European integration, strengthening the "status" of the competence approach in official Ukrainian and international educational documents reorient the traditional educational paradigm of translation of ready knowledge, formation of skills and abilities, to create conditions for acquiring a set of competencies and formation of professional competence, that is, the graduate's readiness for independent, responsible, productive practical activities, flexibility in solving personal and professional problems.

In the scientific literature, the concept of "competence" is currently considered as a characteristic of: an individual, result of education, specialist (official). That is, the concept of "competence" should be considered as a complex, multifaceted integrative ability of an individual to solve professional problems based on experience and competencies. Changes in the determination of educational goals, correlated with the global task of ensuring man's entry into the social world, his/her productive adaptation in this world, necessitate the issue of ensuring a more complete, personality and socially integrated result by the education.

Key words: competence, competencies, competence approach, future specialists, high school.

Стаття надійшла до редакиії 09.05.2020 p. 